\title{
ARISTOCRACIA, PODER E FAMÍLIA EM PORTUGAL, SÉCULOS XV-XVIII
}

\author{
Mafalda Soares da Cunha* \\ Nuno Gonçalo Monteiro**
}

\section{O tema e os problemas}

Importa, antes do mais, delimitar com clareza o âmbito deste texto. Não é nossa pretensão falar de forma detalhada sobre a família aristocrática. Tão pouco buscamos discutir e enumerar todas as múltiplas formas através das quais se exercia o poder social da nobreza, no sentido mais amplamente focaultiano do termo. O que aqui nos interessa é a conexão, historicamente variável, entre as modalidades de constituição da família aristocrática e o exercício do poder político no centro e na periferia. Os poderes que aqui nos interessa são, portanto, aqueles que na ordem jurídica contemporânea se encontram associados ao Estado, ou seja, os cargos de governo no centro - os ofícios nos conselhos palatinos, nas secretarias, no governos das conquistas, nos governos militares - $\mathrm{e}$ as funçōes jurisdicionais e militares na periferia. No centro deste tema está, portanto, a análise da relação entre a coroa e a aristocracia. Mas essa relação, que é mutável, é atravessada, por seu turno, pela tensão entre os grupos nobiliárquicos estabelecidos e consolidados e aqueles, mais recentes ou mais periféricos, que se encontravam em processo de mobilidade social ascendente, parte da qual se materializava, precisamente, através das suas relaçóes com a coroa. Ou seja, embora a relação da aristocracia com o poder político se encontre no núcleo da nossa análise, ela terá, necessariamente de ser articulada com os vínculos estabelecidos com outros grupos nobiliárquicos.

\footnotetext{
* Universidade de Évora - CIDEHUS.

** Instituto de Ciências Sociais - Universidade de Lisboa.
}

Sociedade, Familia e Poder na Península Ibérica. Elementos para uma História Comparativa/Sociedad, Familia y Poder en la Península Ibérica. Elementos para una Historia Comparada, Lisboa, Edições Colibri / CIDEHUS - Universidade de Évora / Universidad de Murcia, 2010, pp. 47-75. 
A nossa abordagem subalternizará, por isso, as questōes estritamente associadas aos seus modelos de organização familiar e de reprodução biológica, concedendo, em contrapartida, protagonismo à evolução das modalidades de intervenção política e à sua periodização. Será, por isso, neste quadro de análise que os recursos da família enquanto unidade de reprodução social - serviços, memória, relações de parentesco e clientelismo, bens e património - serão abordados ${ }^{1}$.

Deste modo, se o nosso ponto de observação é, quase naturalmente, as relaçôes da aristocracia com a coroa há que analisar detidamente as formas pelas quais o grupo se foi sucessivamente reconfigurando ao longo destes quatro séculos, já que se reconhece o seu carácter não estático e rígido. É verdade, porém, que essa plasticidade variou significativamente ao longo do período em análise, desde uma máxima abertura nos séculos XV e XVI até ao progressivo endurecimento das suas fronteiras que atingiu a máxima rigidez no século XVIII. Porém, a perspectiva que aqui defendemos é a de que a coroa portuguesa deteve desde muito cedo um papel extraordinariamente importante na modelação do grupo aristocrático.

Com efeito, o conjunto de dispositivos de ordenamento do espaço social da nobreza que os monarcas portugueses foram aplicando a partir do século XV - Lei Mental, titulação, foros de moradores da casa real, sistema de tratamentos, início da curialização -, criou-lhes condiçôes para se instituírem em árbitros da classificação social oficial. Um pouco mais tarde, os crescentes proventos e novos recursos distributivos gerados pela expansão atlântica e oriental reforçaram a centralidade da coroa, enquanto principal entidade concessora de mercês e recrutadora de serviços militares, administrativos e políticos. É verdade, no entanto, que a coroa não monopolizava ainda a distribuição de cargos e mercês. As casas da rainha, dos infantes e de algumas grandes casas senhoriais dispunham de recursos e poderes, tanto no centro quanto na periferia, também alienáveis e que, em parte, concorriam com a coroa. Se estes factores contribuíram para o crescimento global do grupo nobiliárquico, o acesso aos escalóes superiores da nobreza era controlado pela monarquia, pois era ela a entidade que concedia ou ratificava a titularidade das principais distinções - títulos, jurisdiçōes, cargos na administração central e na corte régia. Uma vez que a hierarquização destas distinções ainda era relativamente indefinida e a sua atribuição social dispersa por um número alargado de linhagens, casas, e indivíduos, a principal consequência traduzia-se na não coincidência entre titulares e aristocracia. Ou seja, se todos os detentores de títulos de nobreza integravam o topo da nobreza, esta abarcava igualmente os senhores de terras, os detentores dos cargos superiores da administração, dos ofícios maiores do paço e, pelo menos, alguns dos

1 Cf. bibliografia citada nas notas subsequentes deste texto. 
alcaides-mores ${ }^{2}$. Por outro lado, e como antes se disse, a administração periférica do território ainda estava efectivamente cometida a particulares leigos ou eclesiásticos. $\mathrm{O}$ conjunto de recursos que estes dispunham tornava-os, assim, relevantes parceiros na gestão política do território e na atribuição de postos e distinções.

Mas esta dispersão política tendeu a reduzir-se significativamente nos séculos ulteriores. A partir da implantação da dinastia brigantina não apenas se restringiu o espaço jurisdicional cometido a privados, como as relações entre a coroa e a nobreza adquiriram maior rigidez, pela progressiva regulação das condições de acesso às distinçōes superiores que tenderam a ser monopolizadas pelo grupo dos titulares.

Tal situação não se traduziu, porém, em restrições à mobilidade social ou à cristalização do grupo nobiliárquico como um todo. Os escalóes inferiores e intermédios do grupo alargaram-se e reconfiguraram-se permanentemente à custa da multiplicação de oportunidades de serviço à coroa que entretanto se verificou. Assim, se no século XVIII a aristocracia tendeu a monopolizar os principais cargos políticos e com eles as principais distinções, há que reconhecer o potencial de mobilidade social conferido pelo desempenho de funções políticas de carácter mais técnico como é o caso dos ofícios judiciais e administrativos nos conselhos e secretarias de Estado, dos postos diplomáticos e dos cargos militares. Por avaliar, com dados empíricos mais consistentes, estão as relações estabelecidas entre estes membros dos segmentos inferiores da nobreza com a aristocracia e o papel desempenhado por essas conexóes na consolidação e preservação do próprio poder da elite aristocrática.

Entretanto, para se ponderar a importância do centro, importa comparar a dimensão dos recursos que este tinha disponíveis, designadamente, comparando Portugal com a Monarquia de Espanha. Desse confronto, há alguns traços essenciais que desde logo sobressaem. Em termos absolutos, a monarquia portuguesa tinha mais recursos para distribuir em matéria de senhorios e comendas: através da Lei Mental, os senhorios doados pela coroa nunca perdiam a sua natureza e podiam a ela reverter, por um lado e, por outro, as comendas das ordens militares eram mais numerosas no reino de Portugal do que em todos os demais da Península. No entanto, apesar do seu dilatado império, o número de ofícios intermédios e superiores (conselhos, governos dos territórios europeus, diplomacia, guerra e conquistas) era mais reduzido em Portugal, pois nunca se alcançaram em número os que a Monarquia Hispâni-

2 Mafalda Soares da CUNHA, "Casas senhoriais, elites políticas coloniais, mobilidade social, dinâmicas sociais (séculos XV-XVII)" in José Jobson ARRUDA e Luís Adão da FONSECA (org.), Brasil-Portugal: História, agenda para o milénio, Bauru/S. Paulo, 2001, pp. 313-342. 
ca, com os seus amplos territórios europeus, dentro e fora da Península, tinha para distribuir, mesmo depois da Guerra de Sucessão. Além disso, a coroa portuguesa, excepto durante o período dos Habsburgo, não teve por prática a venda desses ofícios, como aliás não o fez com títulos de nobreza (barão, visconde, conde, marquês e duque), comendas (aqui houve excepções) e com os senhorios. Assim, a ascensão na pirâmide nobiliárquica só se podia fazer através do serviço à coroa cuja remuneração se traduzia em rendas, títulos e outras distinções. Por essa razão, a monarquia portuguesa acabou por conseguir e por prolongar no tempo e no espaço a ocupação dos cargos no centro e na semi-periferia imperial (governos coloniais) pela mais alta nobreza do reino. Em parte por isso, a associação directa entre aristocracia e o exercício do poder no centro prolongou-se muito mais no tempo em Portugal do que em Espanha, designadamente ao longo do século XVIII. Em compensação, o poder efectivo na periferia, o exercício de jurisdições senhoriais, declinou claramente em Portugal durante a centúria de Setecentos.

\section{Os modelos de organização familiar}

Uma abordagem sistemática e consistente dos processos de estruturação social no Antigo Regime não pode dispensar a ponderação das formas de organização familiar e das relações de parentesco ${ }^{3}$. O ponto de partida deve ser a centralidade que o modelo reprodutivo vincular vai adquirir, ao longo do século XVI, enquanto comportamento de referência para o conjunto das elites sociais. Nos ramos principais da fidalguia antiga a sua adopção traduzia-se, não apenas na fundação de morgadios, mas ainda no encaminhamento de grande parte das filhas e da maioria dos filhos secundogénitos para as carreiras eclesiásticas. A reprodução alargada da "casa» constituía o desígnio estratégico ao qual se deviam submeter todos os destinos individuais. Era este, desde logo, o padrão de comportamento da primeira nobreza do reino ${ }^{4}$.

No entanto, como sublinhou há muito Pierre Bourdieu, se a família, nas suas múltiplas formas, pode ser apresentada como uma «fiction bien fondée», essa forma peculiar de organização familiar que são as «societés à maison ${ }^{5}$ resulta sempre ou de um laborioso trabalho de construção

3 Francisco CHÁCON JIMÉNEZ, "Hacia una nueva definición de la estrutura social en la España del Antiguo Régimen através de la familia y de las relaciones de parentesco", Historia social, no 21, 1995, pp. 95-104.

4 Nuno Gonçalo MONTEIRO, O crepúsculo dos Grandes. Casa e património da aristocracia em Portugal (1750-1832), Parte II, 2a ed., Lisboa, 2003.

$5 \mathrm{P}$. BOURDIEU, "À propos de la famille comme catégorie réalisée", Actes de la 
social ou da especificidade de certas trajectórias no espaço social. Ou seja, só a partir de determinados patamares da hierarquia social esse modelo tendia a ser adoptado. O que significa que só após uma certa acumulação de riqueza e de estatuto social se podia fundar uma casa. Existiam, portanto, modelos alternativos. Um deles era o investimento nas filhas. É nesse sentido que apontam os indicadores para as camadas inferiores da fidalguia nos séculos $\mathrm{XV}$ e $\mathrm{XVI}^{6}$, bem como, numa primeira geração, em outras categorias sociais e em outros séculos. Entre meados do século XVI e meados do século XVII o estudo dos diversos escalóes de clientes da casa de Bragança ilustra bem o contraste entre os fidalgos/comendadores, onde boa parte dos filhos não sucessores se não casava e as filhas eram maioritariamente freiras, e os oficiais do escalão mais baixo, os detentores de benefícios eclesiásticos e de ofícios locais da apresentação da casa de Bragança, que pretendiam aceder a estatutos sociais nobilitantes, para o que investiam preferencialmente nas filhas, encaminhando a maior parte dos filhos para o clero ${ }^{7}$.

O modelo de organização familiar baseado na casa e morgado, portanto, tende a reforçar-se cada vez mais à medida que nos encaminhamos não apenas para os segmentos superiores da hierarquia nobiliárquica, como para os casos em que há uma efectiva consolidação das posições sociais adquiridas.

Acresce, ao que se disse antes, que, conhecendo muitas outras coisas, pouco sabemos sobre os modelos de organização familiar de grupos tão decisivos para a história da alta política como os desembargadores, ou seja, a alta magistratura que era composta pelo escasso número de juristas que atingiam o topo da carreira. Sabemos que a partir de meados do século XVII, de forma mais notória do que o que se verificaria antes, poucos foram os recrutados em casas da alta nobreza, nem sequer de entre os filhos segundos desta, já que se encaminhavam maioritariamente para o clero. Os desembargadores teriam um recrutamento social plural,

recherche en sciences sociales, $\mathrm{n}^{\circ} 100,1993$, pp. 33 e 35 , bem como o conjunto da sua obra sobre o tema.

6 James BOONE, "Parental Investment and Elite Family in Preindustrial States: A Case Study of Late Medieval-Early Modern Portuguese Genealogies", American Antropologist, no 8, 1986; Ivana ELBL, "The Overseas Expansion, Nobility, and Social Mobility in the Age of Vasco da Gama", Portuguese Studies Review, vol. 6, n. ${ }^{\circ}$ 2, Fall-Winter, 1997-98, pp. 53-80; Mafalda Soares da CUNHA, "Portuguese Nobility and the Overseas Government. The return to Portugal (16th to 17th Centuries)", in Ernst VAN VEEN e Leonard BLUSSÉ (eds.), Rivalry and Conflict. European Traders and Asian Trading Networks, 16th and 17th Century, Leiden, 2005, pp. 35-54.

7 Mafalda Soares da CUNHA, A Casa de Bragança (1560-1640). Práticas senhoriais e redes clientelares, Lisboa, 2000, p. 500. 
parte nascidos em meios fidalgos de província ou em fidalgos da corte de segunda ordem, parte em famílias de magistrados há várias gerações, parte em grupos em ascensão, como os negociantes grossistas. Mas, primogénitos ou não, parece certo que uma parte não se casava e que outra se casava notoriamente tarde. $\mathrm{O}$ mesmo se parece poder aplicar a outro pessoal político das altas esferas que não era recrutado na alta nobreza. A tendência dominante para o caso português parece então apontar para a ideia de que entre a nobreza de espada e a nobreza de toga existisse um fosso social raras vezes ultrapassado ${ }^{8}$.

A Restauração de 1640, com a ascensão da dinastia dos Bragança e das casas fidalgas que a apoiaram no golpe em Lisboa e durante a guerra (1640-1668), alterou em parte os comportamentos destas. As grandes casas da dinastia, passaram a monopolizar os principais ofícios da monarquia (governos militares e coloniais, presidências de tribunais, principais dioceses eclesiásticas) e as doações régias em honras e rendas (senhorios, comendas e tenças). As alteraçōes à Lei Mental concedidas após as cortes de 1641 aproximaram a sucessão nestes bens da que se praticava nos bens patrimoniais vinculados. A alta nobreza de corte quase deixou de casar com herdeiras ricas, para se casar apenas dentro do grupo, reforçando a sua identidade e o quase monopólio das mercês régias mais relevantes, tornadas então quase a única fonte de novas rendas. Por outro lado, para além da diversidade dos modelos de organização familiar ou, se se quiser, da pluralidade das formas da família, há ainda que chamar a atenção para os usos e as manipulações políticas do parentesco. Se o modelo de reprodução vincular tem como eixo o parentesco vertical, concentrando na linha dos sucessores os investimentos destinados a perpetuar e engrandecer a casa, o parentesco horizontal, tal como foi muito destacado por alguma historiografia recente, é fundamental nos percursos de mobilidade ascensional. Acresce que as conexōes com os irmãos, tios, parentes, padrinhos e aliados (pelo casamento) foram muitas vezes as mais decisivas e marcantes na constituição de redes e facções mobilizadas para a luta política. Em síntese, este é um aspecto para o qual se deve estar particularmente atento se se quiser apreender com clareza os usos políticos das relações familiares. No mesmo sentido, importa perceber em que medida as redes clientelares das grandes casas foram ou não mobilizadas politicamente.

Com efeito, e retomando a alta nobreza e o sistema de casa, importa saber se houve políticas continuadas das grandes casas e até quando se prolongaram no tempo. Desse modo, ao longo da dinastia de Bragança

8 Cf. José SUBTIL, "Os desembargadores em Portugal", in N. G. MONTEIRO, P. CARDIM e M. S. da CUNHA (org.), Optima Pars. Elites Ibero-Americanas do Antigo Regime, Lisboa, 2005, pp. 253-275. 
vigorou uma intensa disciplina familiar, que impendia tanto sobre filhas como filhos, primogénitos ou não. A todos cabia aceitar o seu destino e contribuir para o acrescentar a casa que lhes dera o ser. Somente no terceiro quartel de setecentos, com a quebra nos ingressos eclesiásticos (tanto masculinos, como femininos), este modelo começou a ser posto em questão.

\section{Periodização da evolução do poder político e a aristocracia}

\section{a) $1385-1640$}

O período cronológico que abrange as dinastias de Avis e dos Áustrias (1385-1640) caracteriza-se por uma razoável continuidade, quer no que respeita o sistema político (fundamentos ideológicos, quadro normativo, tecnologias administrativas), quer no que respeita às características do sistema social, pesem embora algumas especificidades conjunturais que importam sobremaneira ao tema em análise. Assim, apesar de algumas permanências estruturais, as relaçôes entre a coroa e a nobreza e, muito em particular, entre a coroa e a aristocracia sofreram alterações consideráveis que serão explicadas através da relação dinâmica do centro político com o grupo nobiliárquico ao longo destes dois séculos e meio.

Entre as continuidades contam-se as relações de certa forma fundacionais que D. João I (1385-1431), iniciador de uma nova dinastia após a crise dinástica e os conflitos anti-castelhanos de finais do século XIV, e D. Manuel I (1495-1521), chamado a reinar em sucessão de seu primo co-irmão D. João II, estabeleceram com o segmento superior da nobreza e que, até certo ponto, os Áutrias respeitaram. Quer D. João I, quer D. Manuel reforçaram a governabilidade da monarquia, ou, como diria Elias, procuraram controlar a concorrência senhorial, através da concessão de uma série de títulos nobiliárquicos aos seus descendentes directos? ${ }^{9}$. Para o efeito D. João I criou títulos ducais para os seus filhos, novidade que quatro reinados depois $\mathrm{D}$. Manuel repetiu. Alargando um pouco o escopo, note-se que, até 1580 , eram 11 as casas com origem na família real (a de Bragança e as suas ramificações mais estáveis - Tentúgal / Ferreira, Faro / Odemira e Vimioso -, os Aveiro e ainda as temporárias casas de diversos infantes ${ }^{10}$ ) e que perfaziam um terço das casas criadas até essa

${ }^{9}$ Norbert ELIAS, O processo civilizacional. Investigaçôes sociogenéticas e psicogenéticas, Transformaçôes do comportamento das camadas superiores seculares do Ocidente, vol. I, Lisboa, 1989.

10 Enumerando os casos: no século XV, infantes D. Henrique, D. Pedro e D. Fernando, D. Diogo, duque de Viseu, e já no século XVI, aos infantes D. Luís, D. Duarte e D. Fernando. 
data. Temos, pois, não só o escalão cimeiro dos titulares como a bolsa preferencial de recrutamento para a titulação reservados para as casas daqueles que em França se designariam por príncipes de sangue. Com os Áustrias o título ducal permaneceu como prerrogativa dos descendentes das casas geradas entre a família real (Bragança e Aveiro), alargando-se apenas à então terceira casa em ordem de importância no reino, que era a casa dos marqueses, depois duques de Vila Real / Caminha.

Mas existem ainda outras linhas de continuidade. Até à primeira metade do século XVII, cerca de metade da administração do território estava cometida a senhorios - em 1527-1532, 54,5\% do total das câmaras do país estava sob a jurisdição leigos ou eclesiásticos, tendo o número aumentado para $57,6 \%$ em 164011 - em que a parte dos leigos com jurisdição continuou a crescer: 37,9\% em 1527 e 43,5\% em 1640. Diga-se, de resto, que estes dados permitem questionar a periodização da implantação do absolutismo e, mais em particular, a tese que tão amplo eco teve na historiografia portuguesa e que atribui a D. Afonso V (1438-1481) o papel de joguete nas mãos da nobreza pela concessão excessivamente liberal de títulos, terras e mercês e a D. João II (1481-1495) o papel definitivamente disciplinador do grupo nobiliárquico. Como se verá, a oscilação de poder a favor da monarquia resultou bastante mais de factores que na época eram contingentes (recursos ultramarinos) e da consecutiva aplicação das já citadas medidas de ordenamento do espaço social do grupo nobiliárquico do que dos teatrais golpes de força perpetrados por D. João II em 1483 e 1484, não obstante a exemplaridade simbólica de que se revestiram. Assim, as principais diferenças residem nas distintas formas que assumiram as práticas políticas dos agentes e devem, por isso, ser compreendidas em termos diversos daqueles em que a soma das parcelas seja zero. Ou seja, não se trata de avaliar se o poder régio cresceu em detrimento do poder da nobreza, mas sim como evoluíram os difíceis equilíbrios entre as duas partes, podendo-se inclusive admitir que a acumulação de recursos e de funçōes na coroa não significava linearmente uma qualquer perda de poder político do grupo nobiliárquico.

Neste domínio, a literatura historiográfica sobre a Baixa Idade Média permite concluir que a estruturação do grupo nobiliárquico se fazia ainda dominantemente a partir das periferias territoriais. $\mathrm{O}$ mesmo é dizer que os senhores de terras ainda detinham uma significativa capacidade para impor (ou se apropriarem) de mecanismos de extracção da renda a nível local de forma razoavelmente livre. As persistentes queixas

11 Nuno Gonçalo MONTEIRO, "Os poderes locais no Antigo Regime", in História dos Municípios e do Poder Local, Lisboa, 1996, p. 52. Excluíram-se deste cômputo as ordens militares, uma vez que a partir de 1556 foram integradas na coroa. 
dos povos em cortes confirmam-no, tal como demonstram que os donatários tendiam a expandir as suas áreas jurisdicionais tanto à custa dos municípios, quanto de proprietários livres ou até de outros senhores. $\mathrm{O}$ ambiente social era bastante instável e com um nível de conflitualidade elevado. A monarquia detinha insuficientes recursos para disciplinar o grupo senhorial que não raras vezes transferia para o próprio centro político as rivalidades e tensóes que se esgrimiam nas periferias. Ainda longe de procurarem na coroa a arbitragem imparcial, vide judicial, para solucionar os conflitos, esforçavam-se por controlar os centros de decisão política, sem pejo de recorrerem à luta armada para a qual mobilizavam tropas nos seus senhorios. Tal situação justifica os confrontos que, de forma mais ou menos aberta, atravessaram boa parte da segunda metade de Quatrocentos e onde a coroa participou ao lado de um ou de outro grupo nobiliárquico, fenómeno que não se repetiria nos séculos ulteriores. Mas a expansão das áreas de jurisdição resultou também de estratégicos arranjos matrimoniais onde o rei pouco interferia. Alianças que, para mais, consolidavam cumplicidades entre grandes senhores e que não raras vezes foram accionadas nos conflitos internos do grupo ${ }^{12}$.

Este tipo de comportamento perdeu relevo no século XVI, em resultado da acção combinada da maior fiscalização da monarquia sobre os mecanismos de reprodução biológica e social do grupo nobiliárquico e da acumulação de recursos acompanhada por uma maior distribuição de mercês, nomeadamente nas conquistas. Como já foi referido, este aumento da capacidade distributiva da coroa permitiu o reforço dos sistemas de representação da monarquia através do desenvolvimento da corte e da administração central e foi acompanhado pelo alargamento das necessidades de serviço político e militar ultramarinos. Tais factos tiveram consequências demográficas positivas ao nível do conjunto do grupo, embora haja significativas diferenças na hierarquia social por sector de serviço à monarquia.

Assim se o processo expansionista atraiu os segmentos inferiores da nobreza, foi incapaz de cativar a principal fidalguia do reino. Para estes os serviços e os cargos mais honrosos continuavam a ter lugar na corte e os senhorios jurisdicionais no reino permaneciam o principal vector de poder e de distinção social. Poucos fugiram a esta regra, porque poucos tiveram a capacidade de ascender fulgurantemente através da guerra e da

12 Rita Costa GOMES, A corte dos reis de Portugal no final da Idade Média, Lisboa, 1995; Mafalda Soares da CUNHA, Linhagem, Parentesco e Poder. A Casa de Bragança (1384-1483), Lisboa, 1990; Miguel Jasmins RODRIGUES, Organização dos Poderes e Estrutura Social. A Madeira: 1460-1521, Cascais, 1996; Luís Filipe OlIVEIRA, A Casa dos Coutinhos. Linhagem, Espaço e Poder (1360-1452), Cascais, 1999. 
administração ultramarina. Exemplos dessas excepções são as linhagens dos Meneses com Ceuta, as razias, o patrocínio da pequena nobreza e o título de conde de Vila Real e dos Gonçalves da Câmara com a capitania do Funchal, a boa fortuna açucareira e mais tarde os títulos de conde da Calheta e de conde de Vila Franca ou ainda de Vasco da Gama com o descobrimento do caminho marítimo para a Índia, as redes comerciais indianas, a compra do senhorio da Vidigueira a que se seguiu a outorga régia do mesmo título condal. Pouco significativo, sobretudo quando se analisam as trajectórias daqueles que, desde o início da $2^{\mathrm{a}}$ dinastia, ascenderam à titulação e detinham ou foram agraciados com senhorios jurisdicionais e/ou com ofícios palatinos superiores.

Embora, e como se disse, os titulares ainda não coincidissem com a elite do grupo nobiliárquico, importa sublinhar que só um número relativamente restrito de linhagens ascenderam à titulação durante a dinastia de Avis que se pautou por uma prática de outorga ou renovação de títulos extremamente sóbria (em 1580 eram apenas 19 as casas titulares). Em contraste, Filipe II inaugurou uma prática bastante mais generosa, à qual Filipe III e, sobretudo, Filipe IV deram continuidade. Em termos quantitativos o número de casas titulares era quase o triplo em 1640 (55).

No que respeita, porém, aos serviços invocados para a doação de novos títulos verificou-se uma notável continuidade até 1640 . Assim se a maioria dos novos titulares ao longo de todo este período eram não apenas fidalgos, como membros grupos familiares com enraizamento senhorial anterior à crise de 1383-85 (detentores de senhorios e alcaidarias-mores com forte implantação regional), os principais serviços remunerados ao longo do século XV e XVI foram os feitos militares no Norte de África e os desempenhos administrativos no centro e na corte régia ${ }^{13}$. Será todavia importante sublinhar que o arranque, ou ressurgimento, de algumas destas linhagens se devera não ao valimento directo à monarquia, mas à protecção das casas dos príncipes e infantes (casas de Vila Real, de Monsanto, de Portalegre, de Castanheira e de Sortelha),

13 Anselmo Braamcamp FREIRE, Brasôes da Sala de Sintra, 3 vols., Lisboa, 1983. Para a titulação na segunda dinastia ver Luís Filipe OLIVEIRA e Miguel Jasmins RODRIGUES, "Um Processo de Reestruturação do Domínio Social da Nobreza. A Titulação na 2a Dinastia”, Revista de História Económica e Social, n. ${ }^{\circ} 22,1988$, pp. 77-114 e especificamente com D. João III, Jean AUBIN, "La noblesse titré sous D. João III", Arquivos do Centro Cultural Português, vol. XXVI, pp. 417-432. Para o período filipino Mafalda Soares da CUNHA, "Títulos portugueses y matrimonios mixtos en la Monarquía Católica” in Bartolomé YUN CASALILLA (coord.), Las redes del Imperio. Élites sociales en la articulación de la Monarquía Hispánica, 1492-1714, Madrid, 2009, pp. 205-232. Cf. ainda João Paulo SALVADO, Nobreza, Monarquia e Império. A casa senhorial dos almotacés-mores do Reino (séculos XVI-XVIII), dissert. Doutoramento, FCSH-UNL, 2009 (mimeo). 
comprovando a relevância das relações de confiança pessoal dentro do grupo na organização do poder. Já a titulação de dois outros conjuntos de fidalgos decorreu directamente do patrocínio régio: uns em resultado das necessidades de equilíbrio entre facções cortesãs (condes de Linhares, Prado, Torres Novas e Ferreira $\left.{ }^{14}\right)$, factor que, em sentido contrário, também justificou o não encarte em sucessores de títulos (condes de Tarouca, Vila Nova de Portimão, Monsanto, Penela, Sortelha); e outros porque retiraram dividendos directos de carreiras político-administrativas (barão de Alvito e condes de Abrantes, Vila Nova de Portimão, Sabugal e Idanha). Outros ainda, de conjunturas políticas específicas, com particular destaque para o surto de titulações de Filipe II em que se pagaram os serviços à causa e à casa dos Áustria, agraciando linhagens fidalgas com visibilidade bastante mais recente (conde de Sabugal, Idanha, Castelo Rodrigo, S. João da Pesqueira) ${ }^{15}$. Em síntese, uma monarquia que soubera impor um acesso muito limitado ao topo da pirâmide nobiliárquica (que se associava ao título ducal) e conseguia já arbitrar um espaço social ainda fluido e que se pautava por uma grande disputa política e instabilidade nos escalóes imediatos (título condal, sobretudo).

Quanto aos detentores ou beneficiados com senhorios jurisdicionais, o maior número de doações régias foi feito no século XV, sobretudo no início, na sequência da implantação da dinastia de Avis. Mas nem todos os donatários de então vieram a ser agraciados com títulos nobiliárquicos, como é o caso das linhagens dos Azevedos, Coelhos, Cunhas, Cabrais, Lemos, Teixeiras, Sampaios e Melo, etc. ${ }^{16}$. Deve, porém, sublinhar-se que as habilidosas alianças matrimoniais que foram entretecidas ao longo dessa centúria pelos senhores de terras geraram uma apreciável concentração de senhorios jurisdicionais que beneficiaram casas já tituladas ou que alcançaram a titulação. Na centúria de Quinhentos e inícios de Seiscentos esta tendência para a concentração de poder na periferia como fundamento social para a aquisição de um título de nobreza (conde, quase sempre) manteve-se, beneficiando, desta vez, fidalgos-cortesãos eminentes, através de

14 Incluem-se aqui a titulação de duque de Torres Novas do sucessor da casa de Coimbra, resultado da exigência de D. Jorge, por analogia com o título de duque de Barcelos do herdeiro dos Bragança e o acrescentamento ao marquesado de Ferreira do conde de Tentúgal (de varonia Bragança, como se sabe).

15 Alguns destes titulares - os repetidos - antes dos serviços prestados em 1580, distinguiram-se por eminentes carreiras político-administrativas. Mas anteriormente podem apontar-se os casos concretos de Nuno Álvares Pereira, em 1385, o surto de titulações posterior a Toro ou o conde de Borba (futuro Redondo) nas conspiraçôes de 1483-84.

16 Para uma lista completa da situação das terras com autonomia jurisdicional até meados do século XVII cf. António Manuel HESPANHA As Vésperas do Leviathan. Instituiçôes e Poder Político. Portugal-séc. XVII, vol. II, ed. autor, s/d, pp. 9-198. 
estratégicas alianças matrimoniais e do acesso a heranças que eram caucionados politicamente pela coroa, através da dispensa da Lei Mental.

Por fim é de realçar que ao longo de todo o século XVI as maiores casas senhoriais - como as dos príncipes, das rainhas e dos infantes ou as de Bragança, de Aveiro e de Vila Real - porque controlavam extensos territórios, detinham cortes próprias com número de moradores apreciável, criaram um extenso leque de oportunidades de serviço palatino e na administração periférica (judicial, fiscal e militar) o que também contribuiu para a abertura e maior mobilidade dentro do grupo nobiliárquico assim constituindo essas grandes casas em pólos de redes que pressionavam a monarquia para a concessão de cargos e mercês a criaturas suas. $\mathrm{O}$ nível de intervenção política directa no centro por parte dos seus titulares era, no entanto, relativamente baixo, até porque, em muitos casos, o que dominava os seus quotidianos era ausência da corte régia. Veja-se o conhecido caso dos Bragança, dos Vila Real ou dos Aveiro mas também daqueles muitos que nas vésperas de 1580 viviam nas suas terras como são os casos dos marqueses de Ferreira que residiam em Água de Peixes grande parte do ano, dos barôes de Alvito em Alvito, do alcaide-mor de Beja, D. Luís de Sousa, em Beja ${ }^{17}$. Tais evidências podem assim contribuir para refutar a ideia que tem feito curso de as "cortes da aldeia" ou de a residência fora de Lisboa serem uma das reacçôes 'nacionalistas' da principal fidalguia portuguesa à agregação de Portugal à Monarquia Hispânica. Na realidade, antes e depois de 1580, o que, para essas casas ou importante fidalguia, mais importava era a preservação das fontes e das bases do poder senhorial e não tanto a disputa política no centro que estava cometida a servidores com menor pedigree e menos recursos e, portanto, mais necessitados de servir o rei e dele obter novas mercês.

b) $1640-1750$

O período que vai de 1640 até aproximadamente meados do século XVIII pode ser facilmente delimitado em função de alguns critérios essenciais que claramente demarcam o Portugal Restaurado do que o antecedeu. A relativa erosão do poder territorial da alta nobreza e a sua recomposição e transformação numa elite de corte, concentrada em Lisboa, e com um peso relevante no sistema polissinodal da monarquia restaurada é, certamente, um dos mais decisivos.

Embora os contorno da elite titular se tenham começado a desenhar no período da monarquia dual, existiu uma pronunciada ruptura com a Restauração, pelo que em larga medida se pode falar de um processo reto-

17 António Caetano de SOUSA, História Genealógica da Casa Real Portuguesa, tomo X, Coimbra, [1743] 1953; Francisco de Sales LOUREIRO, Uma Jornada ao Alentejo e ao Algarve, Lisboa, 1984, pp. 77-136. 
mado em novos moldes. O número total de casas atingido em 1640, passando das cerca de duas dezenas existentes no início de seiscentos para mais de meia centena, manter-se-á praticamente estável até à última década do século XVIII. No entanto, pouco menos de metade das casas titulares portuguesas desapareceram entre 1640 e 1670 , na maior parte dos casos por razões de opção política ${ }^{18}$, entre estas se incluindo algumas das maiores e mais importantes então existentes. De facto, foram sendo substituídas pela elevação simultânea de outras tantas, recrutadas sobretudo entre os conspiradores de Lisboa de 1640 (os chamados «Restauradores») mantendo-se o grupo muito estável desde cerca de 1670 até praticamente ao século XIX. O fim da Guerra da Restauração (1668) representou, assim, um momento único no que se refere à estabilidade na composição da elite titular da monarquia ${ }^{19}$. O processo de constituição da elite titular da nova dinastia de Bragança coincidiu com a transferência das respectivas residências para a corte. No fim do terceiro quartel de seiscentos a mudança foi radical em relação ao que ocorria no início do século: todos os titulares bem como a maioria dos senhores de terras e comendadores, residiam em Lisboa. Nos finais do século XVII, em geral, quando se fala da fidalguia como grupo, quer-se designar em primeiro lugar a primeira nobreza da corte, que em boa medida já se confundia com os titulares. Ao mesmo tempo, o topo da pirâmide nobiliárquica tornar-se-á muito mais reduzido. E, claro está, as possibilidades de aí ascender mais remotas.

Quanto à evolução política e institucional, passada a conjuntura imediatamente ulterior à Restauração, o pluralismo político e institucional diminuiu claramente no Portugal Barroco. A diferenciação entre a Corte e as províncias parece adquirir, em todos os terrenos, uma dimensão sem precedentes. Depois de 1640 , a coroa portuguesa não teve pela frente, ao contrário de outras monarquias europeias contemporâneas, o desafio constituído por sólidas instituiçōes com forte cunho territorial ou por uma grande nobreza fortemente territorializada. Praticamente todos os corpos institucionais relevantes se localizavam em Lisboa e eram abrangidos pelas malhas da sociedade de corte. Os contrapontos do centro situavam-se numa escala restrita, eram os poderes locais e sobretudo municipais. Tanto mais que uma outra marca característica e distintiva do período pós-Restauração foi, como se destacou, a erosão dos poderes senhoriais, que perderam importância em termos quantitativos, mas também qualitativos. Entre 1640 e o início do século XIX, verifica-se

18 De entre as casas que não desapareceram, diversas foram recreadas ou renovadas em ramos ou gerações distintos daqueles que antes as detinham, apesar dos seus representantes terem reconhecido durante a Restauração os Habsburgos como reis de Portugal (caso do duque de Aveiro e dos condes de Castanheira e de Tarouca, entre outros).

19 Nuno Gonçalo MONTEIRO, O Crepúsculo dos Grandes..., opus cit., pp. 34 e ss. 
uma diminuição bastante significativa do número de terras sujeitas ao senhorio jurisdicional leigo ${ }^{20}$.

Depois de 1640, é no centro da monarquia que se configura a disputa política. $\mathrm{O}$ novo equilíbrio dos poderes no centro não deixa de apresentar algumas semelhanças com o da Espanha dos últimos Áustrias, em particular, de Carlos II. Apesar de as Cortes se terem reunido depois de $1640 \mathrm{com}$ muito mais frequência do que no século e meio antecedente, a sua convocação foi-se espaçando cada vez mais. E, como se recorda em estudo sobre as mesmas, a "política seguiu a partir do últimos anos do século XVII em Portugal um estilo de governação que apontava para a concentração da capacidade decisória e para a restrição do grupo dirigente» ${ }^{21}$. Depois da convocação de 1697 , as Cortes não mais se voltarão a reunir ao longo do século XVIII. O modelo de funcionamento retomado é o "governo dos conselhos» (tribunais) cujo centro é o Conselho de Estado onde se preparam todas as decisóes sobre matérias politicamente importantes, incluindo os processos e consultas relevantes que vinham de outros conselhos. No seio deste sistema polisinodal, pontificam, a par da alta nobreza, os burocratas, os magistrados e algum clero. Mas em posiçōes distintas. Estes marcam presença nos diversos conselhos e na Secretaria de Estado que é então, apenas a do Conselho de Estado. Os Grandes do reino, por seu turno, absorvem as presidências dos tribunais e, tirando certos períodos, como o do valido conde de Castelo Melhor (1662-1667), constituem-se em centro da decisão política pelo facto de monopolizarem o Conselho de Estado. Por isso, mais tarde, algumas vezes se descreveu Portugal em finais do século XVII como uma «república aristocrática».

Tudo isso começa a mudar, embora de forma incompleta, durante o reinado de D. João V (1706-1750). Redefinidas as hierarquias na sociedade de corte pela recentragem da mesma na capela real feita Patriarcal, o Conselho de Estado vai entrar num longo estertor e deixa de se reunir nos anos vinte. Em 1736, sob notória influência da dinastia bourbónica, criam-se três secretarias de Estado. Mas, na verdade, elas não se tornam o centro da decisão política, pois o rei decide com quem quer, à margem dos órgãos formais de decisão política. $\mathrm{O}$ sistema polissinodal já está, em parte, perturbado. Mas o "sistema ministerial», criado no papel, ainda não o substituiu ${ }^{22}$.

20 Bem ilustrado pelas vicissitudes dos clientes das casas senhoriais, designadamente de Aveiro, no município régio de Coimbra, como provou Sérgio Cunha SOARES, O município de Coimbra da Restauração ao Pombalismo, vol. 2, Coimbra, 2004, pp. 331-394.

21 Pedro CARDIM, As Cortes e Cultura Politica no Portugal do Antigo Regime, Ediçóes Cosmos, Lisboa, 1998, p. 92.

22 Baseado em Nuno Gonçalo MONTEIRO, "Identificação da política setecentista. 


\section{c) $1750-1807$}

O último período a considerar (1750-1807) é marcado, assim, pela afirmação do sistema ministerial. De permeio teve lugar o enorme terramoto político, sequência do terramoto natural de 1755, representado pelo período do valimento de Sebastião José de Carvalho e Melo, futuro marquês de Pombal. De facto, o terramoto de 1755 inaugurou uma convulsão mais ou menos contínua, que se prolongou por uma meia dúzia de anos. Num duplo e indissociável sentido, na medida em que não só se traduziu num fortalecimento do poder pessoal de Carvalho, como representou, simultaneamente, um enorme alastramento da esfera de intervenção do Estado (a emergência do Estado Polícia) com a definitiva afirmação das Secretarias de Estado, ou seja, do governo, enquanto centro da decisão política.

Nos meses seguintes ao Terramoto, Carvalho, formalmente apenas secretário de Estado da Guerra e Negócios Estrangeiros, que nos momentos posteriores ao terramoto se acercou da pessoa física do rei, passou a controlar todos os numerosos despachos que o rei foi assinando a partir da Real Barraca armada junto de Belém. A convulsão política permanente, que teve um momento emblemático no atentado perpetrado contra a carruagem em que seguia o rei D. José em Setembro de 1758 e no tremendo suplício infligido em 1759 a alguns dos principais fidalgos do reino nele inculpados (o duque de Aveiro, o conde de Atouguia, o marquês e a marquesa de Távora e dois dos seus filhos) e na prisão de muitos outros, traduziu-se num reforço sem precedentes do poder de Carvalho. Nunca foi formalmente investido no ofício inexistente de "primeiro-ministro", apenas no de secretário de Estado do Reino (1756), mas passou a gozar de um grande ascendente sobre os outros dois (do Ultramar e dos Estrangeiros). Na verdade, as Secretarias de Estado tenderam a despojar os conselhos das suas competências ou a controlá-los politicamente através da sua decapitação e da nomeação de magistrados sintonizados com o gabinete. A esse respeito, uma fonte da época descreve «do expediente que usavam os 14 tribunais desta corte e de como Sebastião José foi debilitando a jurisdição de todos». Esse processo correspondeu também a uma declínio do poder dos Grandes no centro, já fortemente diminuído durante o reinado joanino com o apagamento do Conselho de Estado. Curiosamente, este Conselho supremo foi recriado em 1761, mas os secretários de Estado passaram a integrá-lo por inerência; acresce

Notas sobre Portugal no início do período joanino”, Análise Social, n. ${ }^{\circ} 157,2001$, pp. 961-987; cf., ainda, Luís Ferrand de ALMEIDA, "O Absolutismo de D. João V", in Páginas dispersas. Estudos de história moderna de Portugal, Coimbra, 1995, pp. 183-207. 
que só foi convocado em certos momentos e que os restantes membros nunca se constituíram em barreira sistemática às pretensōes de Carvalho. Este foi elevado à titulação e com a grandeza que era inerente ao título de conde de Oeiras (1761), uma imensa novidade do seu despacho. Pela primeira vez, um secretário de Estado era feito Grande do Reino. A afirmação política e institucional da supremacia do governo tinha agora uma outra expressão. E confundia-se com a consagração pessoal de Sebastião José, ou, mais exactamente, da sua casa.

Curiosamente, durante o reinado de D. José (1750-1777), apesar da supressão de casas titulares por causa do atentado, nem o seu número cresceu de forma notória, nem as mesmas perderam totalmente o seu papel na administração central. Numa monarquia na qual não se vendiam títulos, criaram-se nesses anos 11 casas, tendo desaparecido 9, pelo que existiam em 1777 ao todo apenas 49, nestas se incluindo a do todo poderoso secretário de Estado (marquês de Pombal desde 1770) e dos seu filho secundogénito (conde da Redinha). Os membros da nobreza titular e da primeira nobreza da corte, na qual se devem incluir os filhos segundos dos titulares, perderam durante o reinado boa parte das presidências dos tribunais, viram diminuir o seu peso na diplomacia e começaram a ser menos hegemónicos no alto clero. Mas mantiveram uma clara preponderância no exército (onde os postos de chefia apenas lhes foram disputados por estrangeiros) e nos governos coloniais (vice-reinados da Índia e do Brasil, governos das capitanias principais do Atlântico), nos quais reforçaram a sua posição largamente dominante ${ }^{23}$.

A queda de Pombal em 1777, quando começou a reinar D. Maria I (1777-1816), marcou uma mudança que ficou conhecida pela Viradeira. De facto, durante o reinado anterior, com diversos pretextos, adiaram-se despachos, bloquearam-se os encartes nos títulos, nos bens da coroa (senhorios), nas comendas (em 1777 estavam vagas pouco menos de metade das cerca de 600 existentes), etc., durante um número variável de anos, atingindo-se com isso as muitas grandes casas que se opunham ao ministro. Com a queda de Pombal foi desencadeada uma espectacular inversão na orientação da política de mercês do anterior reinado, despachando-se, nos meses seguintes, as grandes casas aristocráticas nos títulos e bens da coroa e ordens de que usufruíam antes, e nos quais não tinham sido encartadas. Se, o governo só foi parcialmente mudado, a presença de duas destacadas figuras aristocráticas por nascimento (marquês de Angeja e futuro de Ponte de Lima) no mesmo era vista como um indicador da viragem da situação.

No entanto, se as grandes casas viram restabelecido o seu património

23 Baseado em Nuno Gonçalo MONTEIRO, D. José, na sombra de Pombal, 2a ed. revista, Lisboa, 2008. 
em bens da coroa e senhorios, nunca mais voltaram a recuperar o poder político no centro que haviam detido no início do século XVIII. Com efeito, modelo de governo antes esboçado não se iria alterar. Uma das marcas do reinado de D. Maria seria a inexistência de "primeiro-ministro» ou sequer de qualquer personagem politicamente dominante de forma continuada. Tal figura fora formal e politicamente condenada depois da queda de Pombal, e nunca os «ministros assistentes ao despacho» tiveram esse perfil. Apesar do relançamento do Conselho de Estado em 1796, este não só integrava os secretários de Estado, como nunca se substituiu a estes enquanto pólo central da decisão política, embora fosse sempre convocado. De facto, nesse ponto não se voltou para trás, pois, como se afirma numa memória manuscrita datada de 1803 , com a multiplicação dos secretários de Estado «se alterou a forma do governo, e que em lugar de se aperfeiçoar, se multiplica e se fez mais dificultosa (...) Até ao tempo do Marquês de Pombal foram simplesmente uns canais por onde subiam os negócios à presença do Soberano, presentemente são tudo (...) Com esta trincheira de criaturas revestidas d'autoridade, passa-se a tudo, adquirem-se honras, e riquezas, quartam-se as alçadas dos Tribunais, forjam-se Leis Novas, desprezam-se as antigas, alteram-se todas as formalidades (...) segue-se o despotismo Ministerial, que é o maior flagelo dos Povos» ${ }^{24}$. Na mesma memória se defendia que o ofício de secretário de estado fosse trienal...enquanto os membros do Conselho de Estado deveriam ser vitalícios e recrutados apenas na Grandeza! No entanto, o «despotismo ministerial» não iria desaparecer. $\mathrm{O}$ centro de decisão política mudara definitivamente na monarquia.

\section{Diferentes modelos e diversas formas de organização familiar. A efi- cácia da utilização de recursos e fórmulas constantes.}

O acrescentamento das grandes casas aristocráticas constituía um desígnio assumido pelos grupos aristocráticos nos séculos XVII e XVIII. Tal objectivo pressupunha que a casa existisse, com a sua panóplia de símbolos, bens, memórias próprias, etc., o que implicou a aceitação de uma disciplina rígida, que sacrificava os destinos individuais, em prol dos da casa. Implicava igualmente que a coroa aceitasse o pacto tácito com as grandes casas, atribuindo-lhes, em cada geração, os ofícios, honras e rendas que garantiam a sua perpetuação. $\mathrm{O}$ sistema pautava-se, pois, por uma enorme circularidade e, como se sugeriu, excluindo o período de Pombal, como tal aconteceu quase sempre durante a dinastia de Bragan-

24 Marquês de Alorna, Memórias políticas (apresentação de J. NORTON), Lisboa, 2008, pp. 89-92; ao contrário do que se indica nesta edição, é provável que o manuscrito tenha sido escrito pelo $6^{\circ}$ conde de São Lourenço. 
ça (1640-1808). Ora, uma vez que os recursos não eram elásticos, a manutenção das grandes casas significava limites para o número daqueles que podiam ascender a posições sociais similares.

Nesse sentido, ao invés de se caminhar, de acordo com um paradigma evolucionista corrente, em direcção a uma maior abertura, pode dizer-se que as tendências a longo prazo funcionaram em sentido inverso. As oportunidades de ascensão através da política, embora nunca tenham desaparecido, foram certamente maiores na viragem do século XV para o XVI do que dois séculos mais tarde. No século XVI, quando os grandes senhores ainda pontificavam e residiam muitas vezes fora da corte, a presença nos círculos curiais de Lisboa ou da itinerância régia abria as portas à ascensão a fidalgos de província ou de linhagem menos destacada, bem como a juristas e mercadores enobrecidos. Depois de 1640/1668 todos os grandes senhores se deslocaram para o centro e cristalizaram-se os signos de distinção! Havia menos oportunidades para os novos, embora elas existissem.

As trajectórias de mobilidade ascendente ao longo destes quatro séculos assentavam em variados modelos de reprodução social que se prendem, porém e sempre, com a gestão dos recursos familiares. Muitas delas passavam, numa primeira fase, pelo investimento em vários filhos, ou nas filhas. O exercício de cargos políticos, porque quem os desempenhavam tendia a ser remunerado, foi sempre a forma mais consistente de ascensão social, mesmo para os que já tinham acumulado riqueza, pois os ofícios nobilitantes no topo só se venderam de forma muito limitada.

É, pois, a ligação entre trajectórias de mobilidade e o exercício de funções políticas que vamos discutir. Todavia e uma vez que se reconhecem mutações de longa duração sobre as formas de intervenção da coroa na construção das hierarquias dentro do grupo nobiliárquico, optámos pela sua análise em distintas cronologias. Excluímos as trajectórias imperiais, pelo facto de as mesmas revestirem traços específicos, mas integraremos o tópico na análise.

\section{a) Séculos XV - 1640}

Como se referiu anteriormente, a aplicação dos dispositivos institucionais criados pela monarquia vai configurando de forma lenta o espaço social da aristocracia o que tem como principal efeito a maior fluidez e a coexistência de distintos modelos de mobilidade e de reprodução da aristocracia ao longo destes dois séculos e meio.

Neste quadro, parece claro que a questão se deve balizar em torno de duas ou três variáveis cuja combinação resultava na aplicação de fórmulas distintas no que respeita quer às estratégias matrimoniais quer às práticas de heranças. Na base desta formalização está o princípio de que a estratégia de cada grupo familiar visava a maximização dos recursos disponíveis 
num espaço social que estava enformado por constrangimentos legais e ideológicos que eram conhecidos por todos os actores.

No que respeita a partilha de bens parece que a situação variava em função da situação concreta de cada grupo familiar. $\mathrm{O}$ mesmo é dizer que dependia de o grupo familiar estar em fase de implantação de trajectórias ascendentes ou num momento de consolidação de posições adquiridas. No primeiro caso, as estratégias abrangiam a totalidade dos seus membros, o que quer dizer que se tendia a dar estado e a dividir os recursos pelos descendentes. As formas de o fazer eram, porém, variadas. Podiam ser aplicados a) em dotes matrimoniais, normalmente assegurando hipergamia feminina, o que se repercutia em níveis de nupcialidade elevados; b) na criação de vínculos para secundogénitos ou descendentes femininas; c) na transmissão de cargos de juro e herdade e d) de comendas ${ }^{25}$ para filhos segundos. Quando a posição do grupo familiar adquiria uma certa dimensão e se estabilizava esta tendência alterou-se e começou a sobrelevar a tendência para a reprodução concentrada em torno de um único sucessor, procurando-se então uma coincidência na transmissão dos bens da coroa e dos bens vinculares com marginalização de uma parte significativa dos descendentes do estado matrimonial. Entre estes modelos mais extremados é evidente que pontua a plasticidade entre as opções possíveis. O que importa reforçar - e se verificará pelos exemplos de seguida apontados - é a existência de um espaço social mais aberto e mais concorrencial no acesso ao topo da hierarquia nobiliárquica do que aquele que virá a caracterizar o modelo praticado durante a dinastia de Bragança.

Seleccionaram-se, por isso, quatro casos de mobilidade ascendente com variedade de pontos de partida e de trajectórias. Em comum têm, no entanto, a importância do serviço político no reino, o relevo conferido à territorialização do seu poder e a habilidade com que desenharam as estratégias matrimoniais. Se o factor contingente não pode ser iludido, o que convirá ressaltar é a pluralidade de instrumentos e de hipóteses disponíveis para os actores sociais que se traduzem numa razoável capacidade de adaptação às circunstâncias.

O bem sucedido percurso dos grupos familiar dos Lobo da Silveira e dos Carneiro (um para o século XV outro para o XVI) revela as boas hipóteses que servidores não fidalgos encontravam no serviço político-administrativo central. Oriundo de um meio familiar associado à magistratura e à presença física na corte, o doutor João Fernandes da Silveira conseguiu prestígio bastante para contrair matrimónio com uma filha D. Maria Sousa Lobo - de um grupo fidalgo (os Lobo) com implantação jurisdicional no Alentejo. O senhorio obtido quatro geraçōes antes, con-

25 Agradecemos a Fernanda Olival a informação relativa às comendas. 
vertendo Rui Lopes Lobo no $1^{\circ}$ senhor de Alvito, resultara de mercês régias que pagaram feitos militares na crise de 1383-85. A casa detinha um historial relativamente modesto, com um perfil marcadamente regional em que as alianças matrimoniais privilegiaram detentores de alcaidarias mores alentejanas e as redes a clientela do que viria a ser o ducado de Bragança. Acasos fizeram com que os três filhos do $3^{\circ}$ senhor de Alvito morressem precocemente e sem descendência, pelo que no início da década de 1470 foi-lhe concedida a mercê de os bens da coroa serem herdados pela sua filha mais velha que já então era casada e com descendência, a citada $\mathrm{D}$. Maria. Ou seja, se há uma dimensão acidental em esta herança ter recaído numa linha feminina que à partida estava excluída do acesso à sucessão em bens da Coroa, o certo é que entre a fidalguia provincial havia a preocupação de dar estado primeiro às filhas que aos filhos, já que as outras duas irmãs também se casaram e dos três rapazes só de um há notícia de matrimónio. Aos feitos jurídicos do Dr. João Fernandes da Silveira deveu, depois, a casa ser elevada a baronia de Alvito (1475). A política de intenso investimento em alianças matrimoniais foi prosseguida nas duas gerações seguintes, dando estado matrimonial respectivamente a quatro dos seis filhos do $1^{\circ}$ barão e aos 12 que o $2^{\circ}$ barão engendrou (um dos quais bastardo). Nupcialidade particularmente elevada, em que sobressai a tendência para as uniōes com fidalguia cortesã e até titular. O que significa uma prática deliberada de inserção em redes sociais cortesãs, onde avultam grupos familiares destacados na política de então, como os Ataíde (Castanheira) ou os Sousa (Prado). Se a linha primogénita manteve o apelido Lobo associado à herança jurisdicional, os secundogénitos repescaram outros apelidos familiares (Sousa e Silveira) com o objectivo claro de emanciparem as linhas segundas, pelo que adoptaram comportamentos reprodutivos similares aos aqui descritos. Estabilizada a linha primogénita, com o $4^{\circ}$ barão, baixou o número de casamentos dos descendentes, concentrando num sucessor o grosso da herança familiar ${ }^{26}$.

A trajectória de Pedro de Alcáçova Carneiro não deixa de constituir um exemplo quase limite da exploração máxima das oportunidades de ascensão social nos meandros da política cortesã. $\mathrm{O}$ caso está particularmente bem documentado pela singularidade de ele próprio ter deixado relato das diversas etapas e processos do seu fulgurante percurso ${ }^{27}$. As

26 Anselmo Braamcamp FREIRE, Brasões da Sala de Sintra..., opus cit., vol. III.

27 Relaçôes de Pero de Alcáçova Carneiro Conde da Idanha...(1515-1568), Ernesto de Campos de ANDRADA (ed.), Lisboa, 1937 e Manuel José da Costa Felgueiras GAYO, Nobiliário de Famílias de Portugal, tomo III, Braga. Carneiros. Cf. ainda o estudo de Pedro de BRITO, Patriciado Urbano Quinhentista: as famílias dominantes do Porto, 1500-1580, Porto, 1995. 
suas origens familiares paternas - os Carneiro - estiveram, no século XV, ligadas à vereação do Porto, embora os seus ascendentes directos se encontrassem já radicados em Lisboa. Como último filho da extensa prole do secretário António Carneiro, Pedro de Alcáçova teria hipóteses reduzidas de aceder por herança a bens ou cargos relevantes. A inversão da situação foi em grande medida fruto de acasos bem explorados pelo astuto benjamim. A habilidade palaciana do jovem Pedro permitiu-lhe ainda captar as graças e boas vontades dos dois arqui-rivais no valimento régio de então - os condes de Castanheira e do Vimioso. Deles recebeu protecção, apoio pessoal e material. Não o esqueceu, mas as suas memórias acentuaram o carácter determinante da benevolência régia, reconhecendo-se como "feitura de Sua Alteza e obra das suas mãos» ${ }^{28}$. Com efeito, a protecção régia traduzira-se em avultadas mercês: comendas, tenças, direitos de importação de especiarias e sobre a sucessão em bens familiares. Mas o seu posicionamento político após a morte de D. João III, apoiando a rainha viúva em detrimento do cardeal D. Henrique, afastou-o do centro da política activa e criou-lhe, provavelmente, a predisposição para aceitar a subida ao trono de Portugal de Filipe II, o que o Áustria logo premiou elevando-o a conde de Idanha. Os seus sucessores não renovaram, porém, o título, nem alcançaram nunca poder e prestígio similar. De qualquer modo, a estratégia de alianças matrimoniais delineada por António Carneiro (dos seis filhos legítimos casou cinco) integrou logo o grupo familiar nas redes cortesãs, estratégia que o filho Pedro de Alcáçova depois também seguiu (casou quatro dos cinco filhos), assim integrando o grupo familiar no escalão superior da aristocracia portuguesa. Com efeito, a neta, herdeira do primogénito do $1^{\circ}$ conde de Idanha, acabou condessa de Figueiró ${ }^{29}$ e um neto de um ramo secundogénito do secretário obteve, já após a Restauração, o título de conde da Ilha do Príncipe.

Descendente de um ramo segundo da linhagem dos Moura, Cristóvão de Moura desenvolveu uma extraordinariamente bem sucedida estratégia matrimonial da sua rede familiar, à sombra da influência política adquirida junto de Filipe II. Existem numerosos estudos sobre esta personagem e novos trabalhos em curso auguram relevantes contribuições

28 Relaçôes de Pero de Alcáçova Carneiro Conde da Idanha...(1515-1568), opus cit., p. XVII; cf. também Felgueiras GAYO, Nobiliário..., opus cit., vol. III, tit. Carneiros.

29 O título foi outorgado a seu marido Francisco de Vasconcelos, senhor do morgado de Esporão, mas o título incidiu sobre o senhorio que ela herdara. Anedotas portuguesas e memórias biográficas da corte quinhentista..., Christopher LUND (ed.), Coimbra, 1980, p. 89. 
sobre a matéria ${ }^{30}$. Neste contexto valerá apenas destacar os elementos fulcrais para o tópico em análise. Desde logo o facto de a linhagem provir de fidalguia antiga, de senhores de terras. No caso, o senhorio de Azambuja, mas por ramo secundogénito. Os laços matrimoniais do avô, do pai (D. Luís de Moura) e de uma tia paterna de D. Cristóvão estruturaram-se dentro do sistema curial, com particular destaque para as cortes dos infantes. Com efeito, destes três casamentos, dois realizaram-se com oficiais maiores das casas dos infantes D. Luís e D. Fernando (respectivamente a tia D. Guiomar de Moura com um estribeiro de D. Luís e o segundo casamento do pai com uma filha do mordomo-mor de D. Fernando, sendo que deteve ele próprio o cargo de estribeiro-mor do infante D. Duarte). São evidências que servem, assim, para retomar a ideia do importante papel das cortes senhoriais e, em particular, das cortes dos infantes nos processos de mobilidade ascendente da fidalguia menos grada. D. Luís de Moura, apesar de muito pobre ${ }^{31}$, conseguiu consorciar quatro dos seus oito filhos, denotando um comportamento face ao matrimónio dos descendentes já de transição do modelo que se tem vindo a desenhar. Mas foram os serviços prestados e a proximidade a Filipe II que, pela mão de D. Cristóvão, catapultaram este ramo segundo dos Mouras da situação de fidalgotes pobres à Grandeza. No entremeio D. Cristóvão conseguiu estruturar uma sólida e abastada rede à custa de oportuníssimos concertos matrimoniais da sua parentela com herdeiras de casas de senhores de terras (sobretudo dos arquipélagos norte-atlânticos) para quem conseguiu dispensa da Lei Mental. Desde logo para si próprio já que ao unir-se a $\mathrm{D}$. Margarida Corte-Real recebeu uma herança estimada entre 1,6 a 2 contos de reis de renda anual. Mas também para os dois sobrinhos directos (filhos de duas irmãs suas), que fez casar com duas sucessoras de senhorios. E ainda promoveu uniōes em linhagens fidalgas para as suas duas cunhadas Corte-Real e para outras sobrinhas directas! A preeminência adquirida no campo político, que o fizera primeiro conde e depois marquês de Castelo Rodrigo com Grandeza e garantira o título de conde de Lumiares ao seu sucessor, repercutiu-se de forma ainda mais evidente no destino que assegurou aos três filhos. Ao primogénito casou-o com uma filha do conde de Tentúgal / marquês de Ferreira, uma das filhas com o $1^{\circ}$ marquês de Gouveia e a outra, em 1610, com D. Afonso de Portugal, futuro $5^{\circ}$ conde de Vimioso. Alegam,

30 É o caso do projecto de pós-doutoramento de Santiago Martínez em curso no CHAM-FCSH e de trabalhos em curso por João Paulo Salvado.

31 Assim é referido na anedota XCII que traça uma súmula biográfica do seu primogénito, D. Cristóvão de Moura, descrito em criança a brincar nas salas do pai "rotozinho e descalço", Anedotas portuguesas e memórias biográficas..., opus cit., p. 147 . 
de resto, alguns autores que a recuperação da casa dos Vimioso em 1619, que estava confiscada desde a participação do tio deste D. Afonso na aventura promovida pelo Prior do Crato, se deveu à intermediação das relações familiares dos Moura ${ }^{32}$. De "rotozinho e descalço" em criança, D. Cristóvão ascendeu ao cume da pirâmide nobiliárquica onde conseguiu integrar toda a sua descendência, embora depois de 1640 a sua casa só continuasse em Castela. Ou seja, a casa dos Moura elevara-se pela política e foi também em resultado dela que a casa ruiu em Portugal.

O percurso ascensional do grupo dos fidalgos conjurados em 1640 revela, em novo contexto político, o que se pode designar com um verdadeiro 'assalto' ao poder político e com ele a captação das mais altas distinçōes e honras da monarquia. Sem querer repetir o que já foi circunstanciadamente descrito ${ }^{33}$, merece tão só sublinhar-se que este grupo, maioritariamente oriundo de uma fidalguia intermédia ou, em menor grau, de quadros ligados à administração da casa ducal de Bragança, pelos serviços realizados na ruptura e no após $1^{\circ}$ de Dezembro, conseguiu obter de D. João IV uma serie cargos e mercês (na corte, na guerra e/ou na alta administração) que lhe garantiu indiscutível preeminência no Portugal Restaurado. Concomitantemente, a identidade deste grupo dos aclamadores reforçou-se durante o reinado de D. João IV através de casamentos endogâmicos ou, então, de casamentos cruzados com membros de linhagens e casas titulares antigas. $\mathrm{O}$ resultado final espelhou-se na significativa recomposição da elite titular em benefício deste grupo, já que em 1670, 15 casas titulares eram identificáveis com membros da rede dos aclamadores ou dos seus sucessores directos. Constituíam, à época, $30 \%$ das casas titulares existentes em Portugal. Mas mais importante ainda é o facto de, a partir de finais do século XVII, os titulares portugueses terem desenvolvimento um modelo de comportamento e uma relação com a monarquia que praticamente fechou o grupo e o manteve estável até à segunda metade do século XVIII.

\section{b) $1640-1820$}

No período pós-Restauração, a grande nobreza de corte e o demais pessoal político constituíam dois mundos separados do ponto de vista social: os seus padróes de comportamento familiar eram diversos e, com algumas excepções, não se casavam entre si. Com efeito, foram muito poucos os filhos segundos de titulares a seguirem a carreira da magistra-

32 Rocha MARTINS, Os grandes vultos da Restauração de Portugal, Lisboa, 1940, p. 234.

33 Leonor Freire COSTA e Mafalda Soares da CUNHA, D. João IV, 1604-1656, Lisboa, 2007, pp. 29-41 e 330-331. 
tura e raríssimos os magistrados a casar-se com filhas de titulares ${ }^{34}$. Neste período em Portugal não há nenhum esboço de fusão entre «l'épée» e «la robe». Esta foi a regra geral, embora e como sempre se possam enumerar sugestivas excepçôes.

De entre o pessoal político não nascido na aristocracia, os primeiros a furarem esse círculo fechado, no fundo as tais excepçóes, foram alguns secretários de Estado, parte dos quais nem sequer eram juristas. Sublinhe-se, porém, que todos eles (com uma única excepção, o futuro primeiro cardeal patriarca de Lisboa, D. Tomás de Almeida) eram de proveniência exterior à aristocracia ${ }^{35}$.

O caso mais espectacular no século XVII é o dos Monteiros, que durante décadas foram «juízes da inconfidência», algo parecido a chefes da polícia política da segunda metade de seiscentos. Verdadeiramente, o primeiro grande personagem desta história é o doutor Pedro Fernandes Monteiro, de quem se diz que era homem de confiança de D. João IV e que com ele terá passado a Lisboa; mais tarde desembargador, foi ao longo de sucessivos reinados homem de excepcional influência política, juiz da inconfidência e interveniente em grande parte das disputas políticas da época (e na criação da Companhia do Comércio do Brasil), até à sua morte ocorrida em 1673. Sobre o seu pai as versões das fontes são contraditórias, mas sabe-se que era natural da pequena vila alentejana de Monforte e que, na melhor das hipóteses, terá sido juiz dos órfāos e membro da criadagem da casa de Bragança, eventualmente com o estatuto de escudeiro. Tinha, pois, origens inquestionavelmente obscuras e as crónicas da época não poupam Pedro Fernandes, «Ministro que de humildes princípios chegou a ocupar os maiores lugares e adquirir fazenda em cópia», acusando-o de ter injustamente inculpado muitos e de ter feito danos «na honra e na fazenda alheia» 36 . Apesar de todas essas insinuaçōes, o seu filho Roque Monteiro Paim, também jurista, sucedeu-lhe no ofício de juiz da inconfidência, entre outros, e foi personagem da con-

34 Nuno Gonçalo MONTEIRO, «Poderes e circulação das elites em Portugal: 1640-1820», in Elites e poder entre o Antigo Regime e o Liberalismo, 2a ed., Lisboa, 2007, pp. 125-126.

35 D. Tomás de Almeida (1670-1754), antigo secretário de Estado, Bispo do Porto e futuro Cardeal, era filho não sucessor do $2^{\circ}$ conde de Avintes.

36 Monstruosidades do tempo e da fortuna, vol. III, Porto, 1938, pp. 51-52; aí se afirma que se teria arrependido à hora da morte de ter falsamente inculpado Francisco de Lucena e o Conde de Castelo Melhor. Em todo o caso, com a participação de alguns colaterais (como Manuel Monteiro de Vasconcelos, guarda-roupa de D. João IV, que testou bens a favor da descendência de seu primo Roque Monteiro) este foi certamente um caso único antes de Pombal de ascensão dentro da "primeira nobreza» da dinastia de Bragança de quem não provinha de uma linhagem principal do reino. 
fiança de D. Pedro II, chegando a servir interinamente de secretário de Estado. Interveio, também ele, em todas as grandes disputas políticas da época até à sua morte ocorrida em 1704. Acumularam os dois, por doação, compra e herança, um impressionante património em bens de morgado e da coroa e ordens, nestes se incluindo os senhorios de Alva e de Vila Cahiz e várias comendas da Ordem de Cristo ${ }^{37}$. Tendo falecido o único filho de Roque Monteiro Paim, a sua filha primogénita sucessora conseguiu casar com um secundogénito da casa dos condes de Atouguia, depois feito $1^{\circ}$ conde de Alva, e, quando se tornou evidente que não teriam sucessores, casou-se a filha imediata com um secundogénito da casa dos condes do Redondo, em cuja descendência se viria a renovar o referido condado (futuros condes de Alva e marqueses de Santa Iria). Uma casa com outra varonia, pois, mas cujo património tinha sido na sua quase totalidade acumulado no século XVII pelos dois referidos «políticos».

Outros secretários de Estado alcançaram uma significativa ascensão social, mas sem tamanho luzimento. Foi o caso de Diogo de Mendonça Corte Real (1658-1736), antigo diplomata como a maior parte destes, interinamente secretário das Mercês e de Estado durante a Guerra da Sucessão de Espanha e depois, sem interrupções, secretário de Estado e homem da confiança de D. João V entre 1707 e a sua morte. Entre outros comentários, dizia-se numa fonte de 1714 que este desembargador e antigo enviado diplomático à corte de Madrid era «oriundo de uma família pouco conhecida do Algarve (...) e, ao que parece, bastante pobre. Nunca se quis casar para não ter de fazer fortuna para os seus filhos» 38 . $\mathrm{Na}$ verdade, era filho de desembargador e descendia de uma linhagem fidalga algarvia com alguma prosápia ${ }^{39}$. Mas o maior erro foi o do prognóstico antes citado. Com efeito, pouco depois do regresso a Lisboa, agora como Patriarca, de D. Tomás de Almeida que antes substituíra no ofício de secretário de Estado, Diogo de Mendonça tornou-se seu cunhado (1718), ao casar-se com mais de sessenta anos com uma irmã viúva e já avantajada nos anos de quem teve, porém, descendência. No entanto, embora tenha tido um filho bastardo secretário de Estado da Guerra e Ultramar $^{40}$ e a casa do seu primogénito alcançasse comendas das ordens

37 Sobre o impressionante património desta casa, cf. Nuno Gonçalo MONTEIRO, O crepúsculo..., pp. 268-271.

38 Nuno Gonçalo MONTEIRO, O crepúsculo..., opus cit., p. 146.

39 Cf. Damiāo António LEMOS de FARIA e CASTRO, Política Moral e Civil, Aula da nobreza Lusitana, tomo IV, Lisboa, 1751, pp. 551-577.

40 Quem veio a suceder anos mais tarde a Diogo de Mendonça Corte Real no ofício não foi um filho do seu casamento antes referido, mas um filho bastardo homónimo do Secretário de Estado de D. João V, que desempenhou várias missões 
militares, não chegou a estar na origem de uma casa titular e o seu património nunca alcançou o da casa do antes referido Roque Monteiro Paim.

Outros secretários de Estado conseguiram casar também já em idade avançada com filhas da primeira nobreza. Mas nenhum teve uma ascensão comparável à de Sebastião José de Carvalho e Melo $(1699 / 1782)^{41}$. Nascera numa casa fidalga relativamente antiga, contando entre seus ascendentes uma autêntica dinastia de desembargadores e muitos parentes com relevo. Não pertencia, no entanto, à primeira nobreza da corte, apesar do pai ter chegado a receber a doação de uma comenda. Primogénito de uma vasta prole, na qual se destacariam dois dos seus irmãos que com ele colaboraram, para além de várias irmãs freiras, não contava a casa chamada dos Carvalhos da Rua Formosa, em Lisboa, senão com um rendimento limitado em bens vinculares e outros, matéria que não seria de pouca monta na sua trajectória. $\mathrm{Na}$ casa de seu pai, capitão de cavalos e genealogista de méritos discutíveis, funcionou uma academia literária, antes da morte deste em 1720. Não é certo que tenha frequentado a Universidade de Coimbra, sendo seguro que foi militar por muito pouco tempo. Com vinte e três anos casou-se com D. Teresa de Noronha e Bourbon (1689-1739), viúva e doze anos mais velha, filha de um filho não sucessor do $3^{\circ}$ conde dos Arcos, e da herdeira e senhora donatária de Carvalhais e Ílhavo. Tendo-se este enlace realizado, segundo alguns, contra a vontade dos parentes da noiva, o certo é que o casal se retirou por motivos ainda não de todo esclarecidos entre 1723 e 1731 para uma quinta próxima de Pombal. À protecção de seu tio, o arcipreste da Patriarcal e desembargador terá ficado a dever o ingresso em 1733 na Real Academia de História. Sem quaisquer serviços anteriores à monarquia, o que de resto aconteceu com cerca de um quarto dos diplomatas portugueses, mas apenas com alguma fama de erudito e possivelmente protegido pelo seu primo Marco António de Azevedo Coutinho, acabado de ser elevado a secretário de Estado, bem como pelo padrasto, o chanceler da Relação do Porto, Carvalho foi indigitado para enviado extraordinário na corte de Londres, para onde partiu em 1738. Aí redigiu, como competia no âmbito da sua actividade, prolixos relatórios, de forte pendor mercantilista, sobre as relações comerciais entre a Inglaterra e Portugal, para além de ter recebido a notícia da morte da primeira mulher. De passagem por Lisboa desde finais de 1743, foi nomeado no ano seguinte

diplomáticas e foi Secretário de Estado desde 1750 até 1756, altura em que foi encarcerado, como tal permanecendo até à sua morte; cf. Artur LAMAS, A quinta de Diogo de Mendonça no sitio da Junqueira: (extra-muros da Antiga Lisboa), Lisboa, 1924 .

41 Nuno Gonçalo MONTEIRO, D. José..., opus cit. e fontes e bibliografia aí citadas. 
enviado, só depois com estatuto de «extraordinário», à corte de Viena, com o objectivo de intermediar em nome de Portugal o conflito daquela corte com Roma. Geralmente, têm-se feito um balanço pouco brilhante desta missão, no decurso da qual teve enormes conflitos com o representante de Portugal junto da Santa Sé. Mas, de lá trouxe um precioso segundo casamento, celebrado em Dezembro de 1745 com D. Maria Leonor Ernestina, condessa de Daun, da mais elevada nobreza imperial e sobrinha do célebre Marechal Daun, que não poucas portas haveria de lhe abrir. Considerado pelo cardeal da Mota como um "erudito» com "talento e prudência», Carvalho era um dos potenciais candidatos na nova situação que se avizinhava.

Do seu ulterior destino político já antes se falou. Por decreto de 1759, Sebastião José foi despachado pelos serviços do seu tio e pelos seus próprios na diplomacia e nas secretarias de Estado até aquela data, com o título de conde de Oeiras de juro e herdade, o senhorio daquele lugar erigido em vila, o relego e reguengo de Oeiras, o senhorio de Pombal e provimento das respectivas justiças e, por fim, numa comenda da Ordem de Cristo. Além de muitas outras mercês régias, foi feito em 1770 marquês de Pombal, como se disse. Mas, para além disso, construiu uma imensa casa, uma das quatro casas aristocráticas com maiores rendas em Portugal em finais do Antigo Regime. Com um traço bem peculiar: ao contrário de todas as restantes, retirava mais de metade das suas rendas de bens situados em Lisboa, boa parte dos quais situados na zona edificada depois do Terramoto ${ }^{42}$. Foi por isso, tal como o tinham sido os Monteiro e tantos outros antes deles, acusado de enriquecimento ilícito. De que se defendeu enfaticamente: "Considerando sua Majestade que não seria decoroso ao seu carácter Régio, que a casa de um Primeiro Ministro de quem tinha confiado os maiores negócios do Reinado, ficasse confundida entre as menos consideráveis de Portugal; contra os Exemplos do que os Reis Henrique IV, Luís XIII e Luís XIV haviam praticado com o referido Duque de Sully; com o Cardeal Richelieu; com o Cardeal Mazarino; e contra o que outros Grandes Monarcas haviam também praticado em casos semelhantes» ${ }^{43}$. De acordo com parâmetros tradicionais, Pombal, que pouco tempo depois negaria ter sido alguma vez «primeiro-ministro", não dissociava a sua autoridade política do seu estatuto social e da sua riqueza. Que lhe sobreviveria, tal como as alianças dos seus descendentes dentro da primeira nobreza do reino.

Nas matérias referidas, o caso de Pombal ilustra bem como, até finais do século XVIII, prevaleciam ainda os mesmos valores que dominaram nos séculos antecedentes. Ao invés da modernidade meritocrática

42 Cf. Nuno G. MONTEIRO, O crepúsculo..., opus cit.

43 BNL, Pombalina, códice no 695. 
geralmente atribuída ao século dito das Luzes, prevaleciam ainda concepções que associavam a apetência e a competência para o mando à nobreza e à riqueza. Mas algo mudara, porém: como alguns mostram em tom crítico, eram agora os ministros que se tornavam titulares e não tanto os titulares que se tornavam ministros.

\section{Conclusão}

Da conexão entre família e poder muito se tem falado na historiografia recente. O tema corre, até, o risco da banalização. Muito sinteticamente no que à aristocracia respeita valerá a pena sublinhar o significativo corte que se verifica nos modelos de organização familiar do grupo no seu todo em meados do século XVII. Ou seja, até então a familia aristocrática era mais extensa numericamente, socialmente mais diversificada e com práticas de reprodução biológica mais plurais. Nela se englobavam assim todos os que residiam sob a autoridade do pater familias, o que significava não apenas os consanguíneos dependentes, como a criadagem doméstica que integrava tanto os criados de origem fidalga como de raiz mecânica e escrava. E que em alguns casos podia mesmo apresentar-se sob a forma de cortes senhoriais. O poder senhorial estruturava-se e assentava, de facto, mais sobre as periferias territoriais do reino do que no centro político, abrindo espaço a redes clientelares geográfica e socialmente bastante diversificadas e com capacidade reprodutiva bastante autónoma da coroa. Quase em tudo ao invés do que ocorrerá posteriormente a 1640, quando a definitiva curialização em Lisboa relega o exercício do poder territorial (e consequente estreitamento dos dependentes directos) para um papel secundário na economia da reprodução da casa, ao mesmo tempo que tende a retirar autonomia reprodutiva aos descendentes, garantindo uma estreita disciplina familiar que apostava apenas na manutenção e sobrevivência da casa concentrada em torno do reprodução biológica do ramo principal do agregado familiar.

Mas em termos comparativos com Castela, o que será que se podem considerar serem as singularidades portuguesas? As semelhanças são grandes, mas ajudam a perceber as diferenças. A curialização que no reino vizinho tem lugar com os Áustria, só ocorreu em Portugal com os Bragança (1640-1668), mas é, certamente, levada muito mais longe: todos os titulares viviam em Lisboa nesta última data. Acresce que o controlo dos Grandes sobre os destinos da monarquia, que em Espanha sofreu uma ruptura com os Bourbon (1701), se prolongou em Portugal pelo menos até cerca de 1725-1750. E, depois, eles mantiveram um peso decisivo no exército e nos governos do império e, pelos filhos segundos, no alto clero. Essa diversidade política traduz, em larga medida, uma diversidade institucional: em Portugal não se compravam títulos de 
Grandes - era necessário serviço ao rei para se obterem; o rei tinha muito mais para distribuir, mais comendas e muitos senhorios - a alta nobreza dependia materialmente da coroa e nunca pôde, como aconteceu no século XVIII espanhol, apartar-se do serviço ao rei para regressar aos seus senhorios.

\section{Bibliografia seleccionada}

BOONE, James, "Parental Investment and Elite Family in Preindustrial States: A Case Study of Late Medieval-Early Modern Portuguese Genealogies", American Antropologist, n. ${ }^{\circ}$ 8, 1986.

BRITO, Pedro de, Patriciado Urbano Quinhentista: as famílias dominantes do Porto, 1500-1580, Porto, 1995.

COSTA, Leonor Freire e CUNHA, Mafalda Soares da, D. João IV, 1604-1656, Lisboa, 2007.

CUNHA, Mafalda Soares da, A Casa de Bragança (1560-1640). Práticas senhoriais e redes clientelares, Lisboa, 2000.

ELBL, Ivana, "The Overseas Expansion, Nobility and Social Mobility in the Age of Vasco da Gama", Portuguese Studies Review, vol. 6, n. ${ }^{\circ}$ 2, Fall-Winter, 1997-98, pp. 53-80.

GOMES, Rita Costa, A corte dos reis de Portugal no final da Idade Média, Lisboa, 1995.

MONTEIRO, Nuno Gonçalo, Elites e poder entre o Antigo Regime e o Liberalismo, 2a ed., Lisboa, 2007.

MONTEIRO, Nuno Gonçalo, O crepúsculo dos Grandes. Casa e património da aristocracia em Portugal (1750-1832), 2a ed., Lisboa, 2003.

OLIVEIRA, Luís Filipe e RODRIGUES, Miguel Jasmins, "Um Processo de Reestruturação do Domínio Social da Nobreza. A Titulação na 2a Dinastia", Revista de História Económica e Social, n. ${ }^{\circ} 22,1988$, pp. 77-114.

SUBTIL, José, "Os desembargadores em Portugal", in N. G. MONTEIRO, P. CARDIM e M. S. da CUNHA (org.), Optima Pars. Elites Ibero-Americanas do Antigo Regime, Lisboa, 2005, pp. 253-275. 